\title{
Issues faced by micro entrepreneurs in banking: A comparative analysis of public and private sector banks
}

\section{WASEEM KHAN AND SANA FATIMA}

Received : 20.02.2017; Revised : 15.03.2017; Accepted : 25.03.2017

\begin{abstract}
Banking is one of the fastest growing industries in India. In spite of dominant position of public sector banks private sector banking in India revolutionizes the business environment. But micro enterprise in India is still under developed due to financial hindrance while they account good share in production and export. For the development of micro enterprises there should be a strong linkage with the banks. A primary study of 80 respondents has done to identify the issues associated with banking. Simple statistical technique chi-square and ANOVA is used to analyze the data. This study is helpful for banks to design a policy to deliver the service particularly to micro enterprises.
\end{abstract}

KEY WORDS : Banking, Microenterprises, Economic development

How to cite this paper : Khan, Waseem and Fatima, Sana (2017). Issues faced by micro entrepreneurs in banking: A comparative analysis of public and private sector banks. Internat. J. Com. \& Bus. Manage, 10(1) : 48-53, DOI: 10.15740/HAS/IJCBM/10.1/48-53. 